\title{
Effect of Mobile Communication Services on Performance of Saccos in Kenya
}

\author{
Mugo, David Muchangia \\ School of Pure and Applied Sciences, University of Embu, Embu, Kenya \\ Muathe, S.M.A \\ School of Business, Kenyatta University, Nairobi, Kenya
}

Waithaka, Stephen Titus

School of Engineering and Technology, Kenyatta University, Nairobi, Kenya

Doi: 10.19044/esj.2018.v14n30p46 URL:http://dx.doi.org/10.19044/esj.2018.v14n30p46

\begin{abstract}
The ubiquitous nature of mobile technologies and devices, present new challenges and opportunities for Deposit-Taking Savings and Credit Cooperative Societies (SACCOs) as they integrate them into their processes with the hope of improving their performance. To enhance their performance, Deposit-Taking SACCOs have adopted and are using mobile communication services including mobile messaging, mobile call services, mobile email, mobile chatting and mobile conferencing services. However, the effect of these mobile communication services on performance of Deposit-Taking SACCOs has not been well studied. Even though some studies have indicated the positive potential of mobile communication services, other studies indicate that they have no effect on organizational performance. Given these contradictions, this study sought to investigate the effect of mobile communication services on performance of Deposit-Taking SACCOs in Kenya. Descriptive and explanatory research designs were adopted using quantitative and qualitative approach to data collection, analysis and reporting. The study used a sample of 86 Deposit-Taking SACCOs drawn from a target population of 110 Deposit-Taking SACCOs that were licensed by SACCO Societies Regulatory Authority as at $31^{\text {st }}$ December 2011. A structured questionnaire administered to two managers (from information technology and finance departments) in each SACCO was used to collect primary data. Inferential analysis revealed the exististence of statistically significant positive effect of mobile communication services on performance of Deposit-Taking SACCOs in Kenya. The study therefore recommends investments and increased utilization of mobile communication services within DepositTaking SACCOs in Kenya.
\end{abstract}


Keywords: Mobile messaging, mobile call services, mobile email, mobile chatting and mobile conferencing services

\section{Introduction}

Rapid evolution in mobile computing has driven new directions in the growth of economy particularly the financial sector. The rapid advances in mobile technologies and the increased coverage of mobile networks present new opportunities for integrating mobile technology services into existing financial services delivery models as well as driving innovations leading to new financial solutions' delivery channels. Infrastructure barriers (especially in remote areas) associated with desktop computers and non-portable traditional technologies are addressable by utilization of mobile devices since they provide mobile technology services from any location and at any time conveniently to their users (Liang et al., 2007; Dineshwar \& Steven, 2013).

Mobile technology services are classified in different ways. Rao et al. (2007) classify them into messaging services (that allow use of short message services for communication), mobile content and information services (that provide mobile devices' users with information in various modes), and transaction-based services (that enable transactions such as money transfer, mobile bill payments, and mobile account opening). Mobile technology services have also been classified based on targeted users that is business-tobusiness, business-to-consumer and business-to-employee services (Rangone $\&$ Renga, 2006). In place of mobile technology services, other more specific terms have been quoted in existing literature. These terms include mobile business applications (Scornavacca \& Barnes, 2006), mobile office services (Vuolle, 2010), and sales force automation applications (Evans, 2002) among others.

Mobile communication services refer to use of mobile devices to facilitate exchange of business information through mobile calls, mobile messaging, mobile email, mobile chatting services and mobile conferencing services. Mobile communication services allow communication from anywhere to any person, which is crucial in overcoming geographical barriers by allowing parties involved to save on transport costs. It is also essential for timely delivery of information and knowledge by an organization's employees, managers and other stakeholders. Information is regarded by economists as a critical element in the efficient functioning of markets and therefore important towards enhancing performance of firms (Jensen, 2007).

\section{Deposit-Taking SACCOs in Kenya}

The financial sector comprises players from the banking industry, microfinance institutions, capital markets, insurance companies, savings and credit cooperative societies (SACCOs), mutual funds and development 
finance institutions each playing a role in provision of diverse financial solutions. A SACCO system is a type of credit unions owned by members sharing a common interest in order to mobilize savings to facilitate credit and other financial services to themselves (World Council of Credit Unions, 2013). Credit unions evolved from the cooperative activities of early $19^{\text {th }}$ century from the idea that people could pool their money and make loans to each other. The first of these cooperatives emerged in Germany and England before spreading to other countries (World Council of Credit Unions, 2013).

The SACCO subsector in Kenya comprises of Deposit-Taking and non-Deposit-Taking SACCOs. Deposit-Taking SACCOs are licensed, supervised and regulated by SACCO Societies Regulatory Authority (SASRA) under the SACCO Societies Act of 2008 (Mumanyi, 2014). Deposit-Taking SACCOs unlike non Deposit-Taking SACCOs offer front office saving activities (FOSA) which allow them to provide simple banking services to their members/customers (such as taking deposits, payment services, automated teller machines and other quasi banking services) thus improving their working capital.

Based on their membership, Deposit-Taking SACCOs are categorized into teacher based, Government based, farmers based, private institutions based and community based SACCOs (SASRA, 2013). Majority of the members of Government based SACCOs comprise employees of Government Ministries, Departments, State Corporations, Public Universities and Colleges and County Governments. For farmer based SACCOs, majority of the members are farmers engaged in different agricultural activities (both direct and indirect activities) in various parts of the country while private institutions based SACCOs have members who are mainly employees of private organizations including non-Governmental organizations operating in Kenya. Community based SACCOs have members who are mainly residents of a given geographical area engaged in a productive economic activity while teacher based SACCOs have membership mainly drawn from employees of public/private schools, colleges and universities (both public and private).

The Deposit-Taking SACCOs account for three quarters of the SACCO subsector's assets, deposits and membership (SASRA, 2013). SubSaharan Africa remains the region with the lowest deposit-taking institutions penetration in the world which stands at an average of $16.6 \%$ compared to $63.5 \%$ in developed countries and therefore the need to have Deposit-Taking SACCOs to fill this gap (Savings Plus, 2010). In line with the Kenya's Vision 2030 strategy (that requires financial organizations to increase savings and to mobilize more investments for economic growth and development of the country) Deposit-Taking SACCOs' role in the Kenyan economy remains paramount (Government of Kenya, 2013). Given that only about 19\% of Kenyans have access to banking services, services provided by Deposit- 
Taking SACCOs are expected to be vital towards enhancing the reach and access to financial services particularly for citizens living in rural areas (Olando, Mbewa \& Jagongo, 2012). By the year 2009, out of the 20 million adult people in Kenya, $22.5 \%$ were served by commercial banks and MFIs while $17.6 \%$ were served by SACCOs making SACCOs a key player in Kenya's financial sector (Matumo, Maina \& Njoroge, 2013).

\section{Statement of the problem}

Kenya's Vision 2030 requires a vibrant and a stable financial system to mobilize savings, and to allocate resources more efficiently in the economy (Government of Kenya, 2013). Deposit-Taking SACCOs are expected to play a key role towards the realization of this vision especially by connecting people who have been financially excluded by major banks to financial services. Although Deposit-Taking SACCOs have embraced prudent norms in credit risk management as expected by their regulator, SASRA, SACCOs still have a problem of non-performing loans which was recorded at 4.7 percent in 2013 and 5.73 percent in 2014 (SASRA, 2014). Additionally, SASRA (2013, 2014) noted that many SACCOs had not yet managed to comply with capital adequacy ratios.

Deposit-Taking SACCOs also face high demands for loans which might be incompatible with the available funds given that they cannot seek credit from the Central Bank of Kenya like other commercial banks (Mugambi et al., 2015). Therefore it implies that when faced with cash problems such as in time of business difficulties or in case of excessive demands for loans, they have nowhere to turn to. Deposit-Taking SACCOs are therefore prone to liquidity shortage which has the potential to greatly bring down any financial institution as noted by Mugambi et al. (2015). Additionally, they continue to face stiff competition from other deposit taking institutions particularly commercial banks (Matumo et al., 2013; SASRA, 2013).

Although various scholars have asserted that mobile technology services particularly mobile communication services have the potential to cause business performance outcomes including organizational efficiency, increased number of customers, service quality in business, competitive advantage, cost savings, increased productivity, increased knowledge sharing, employee satisfaction, increased profitability, increased amount of data processing and operational performance (Kagan et al., 2005; Zhang \& Mao, 2008; Abadi, Kabiry \& Forghani, 2013; Aboelmaged \& Gebba, 2013; Maina \& Gekara, 2014; Stoica, Mehdian \& Sargu, 2015), these benefits are yet to be confirmed in studies covering Deposit-Taking SACCOs. Additionally, some scholars assert that despite mobile technology services having significant benefits for citizens using them, organizations that employ 
them are yet to realize notable gains in productivity from them (Dineshwar \& Steven, 2013; Orotin, Quisenbery \& Ted, 2013). Further, despite the potential of mobile technology services, SASRA (2011) raised concerns in regard to increased incidences of fraud among Deposit-Taking SACCOs raising deep questions on the role of ICT towards the performance of this sector.

Lack of understanding the implication of these mobile technology services might lead to Deposit-Taking SACCOs investing in unproductive technology and or refusing to adopt technologies that might cultivate competitive advantage for them (Gunasekaran, Ngai \& McGaghey, 2006). Therefore, given the contradicting evidences in literature on the effects of mobile technology services on organizational performance, the researcher found it necessary to conduct a study to investigate the effect of mobile communication services on performance of organizations. This study was contextualized within Deposit-Taking SACCOs in Kenya given their performance challenges and a dearth in literature regarding their performance.

\section{Research Hypotheses}

The study collected and analyzed data to test the following hypotheses:

H01: There is no statistically significant effect of mobile messaging services on performance of Deposit-Taking SACCOs in Kenya

H02: There is no statistically significant effect of mobile call services on performance of Deposit-Taking SACCOs in Kenya

Ho3: There is no statistically significant effect of mobile email services on performance of Deposit-Taking SACCOs in Kenya

H04: There is no statistically significant effect of mobile chatting services on performance of Deposit-Taking SACCOs in Kenya

Hos: There is no statistically significant effect of mobile conferencing services on performance of Deposit-Taking SACCOs in Kenya

\section{Literature Review}

Several studies have been conducted to establish the effect of mobile communication services on organizational performance. Kiganane, Bwisa \& Kihoro (2012) found that mobile call service had the greatest effect on improving firms' performance. Other services such as mobile messaging, mobile email, mobile chatting and mobile conferencing also constitute mobile communication but were left out in the study. Another study combining all these mobile communication services on organizational performance is therefore important and was the focus of this study.

In another study by Maina, Bwisa \& Kihoro (2012), mobile phone services were found to have significantly increased sales volume, profit, worker productivity, and customer satisfaction ratings. The study was based on the use of longitudinal data from manufacturing firms and considered six 
mobile technology services that were listed as mobile calls, mobile internet services, mobile banking, mobile messaging, M-Pesa and mobile bills payment where mobile calls, mobile messaging and M-Pesa were the only significant variables in determination of firms' performance. As the study by Maina et al. (2012) was exploratory in nature, further studies are required to confirm their findings especially in other sectors of the economy using other research designs such as explanatory design. This study sought to address this gap by covering additional mobile technology services such as mobile advertising, mobile deposits, mobile statements, and mobile chatting among other mobile technology services and in a different sector, that is, SACCO sector.

Wahla \& Awan (2014) noted that use of mobile phones for communication improved working efficiency of employees in Pakistan industries as they could easily contact their colleagues for purposes of sharing thoughts and knowledge. Although the respondents in the study admitted using mobile phones for personal issues such as calling their family members and sending messages to their loved ones, they nonetheless argued that their productivity was greatly enhanced through mobile communication services especially to their colleagues on work related issues. Some respondents even indicated that they could not manage to work without their mobile phones as they needed to make enquiries related to their tasks from time to time to both their managers in other offices and their colleagues. This study was conducted to establish how mobile communication services affect not just individual performance but the overall organizational performance which was not addressed by Wahla \& Awan (2014) in their study.

Salia, Nuamah \& Steel (2011) found in their study that market efficiencies improved and price variations reduced as a result of better availability of up-to date information. Their study aimed at investigating the effect of mobile communication on market efficiency and livelihoods in Ghana. In their study, they argued that mobile communication services enabled fishermen towards improving their incomes and expanding markets for their produce. Additionally, the study noted that mobile communication improved the livelihoods of the fishermen as it facilitated the staying in touch with their families. Mobile communication services are now embraced by SACCOs to communicate with their members on various organizational products and services. According to International Telecommunication Union (2013) mobile communication services, which are currently the most widely used form of mobile technology services, include SMS, MMS, e-mails, and mobile chatting. This study was important in validating the benefits of mobile communication services within the context of an organization.

In their study, Smits \& Mogos (2013) found that social media enhanced business capabilities of an advertising company. The study also 
found that improved business capabilities led to improved business performance for the company. They noted that social media tools are an ecosystem of various tools that allow communication through chatting and advertising by organizations. Another study by Njeri (2012) found that commercial banks have embraced social media interaction where Facebook is the dominant platform with the highest number of users and the most commonly used for interaction between firms and customers. Njeri (2012) noted that social media interactions offers a platform for marketing and sales of products, development of new product brands, and access to real-time customer feedback to enhance banks' understanding of the needs of their customers. It would be interesting to also study how social media services such as advertising and communication via chatting and conferencing services affect the performance of Deposit-Taking SACCOs.

Kimani (2005) noted the crucial role played by social media marketing on performance of organizations in Kenya. In her study, she argued that through marketing via social media, organizations can benefit in terms of improving their brand awareness, real-time communication and repeat exposure. She also argued that social media can greatly enhance the competitive advantage of an organization by facilitating real-time responses to customers' concerns, by monitoring brand information and by enabling generation of demographic profiles of its customers. This study included conferencing and chatting services provided by social media to establish how they affect the performance of SACCOs in Kenya.

\section{Conceptual Framework}

Based on the review of the literature, the study proposed that the performance of Deposit-Taking SACCOs is affected by mobile communication services as captured in the conceptual framework shown below: 


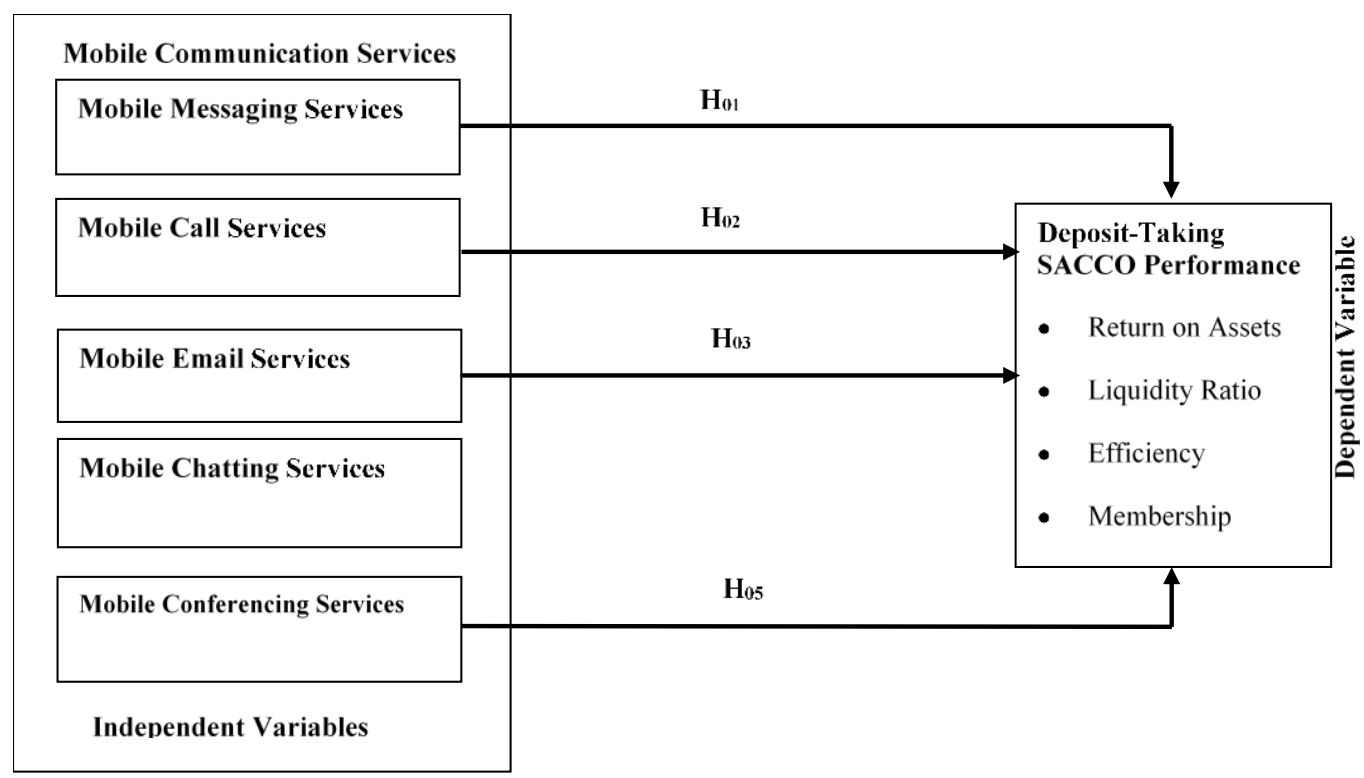

Figure 1: Conceptual Framework

\section{Methodology}

This study was guided by positivism paradigm. It was an ideal philosophy for this study as scientific processes were followed in formulation of the hypotheses and deductions of the observations in order to determine whether to reject or not to reject the formulated hypotheses as recommended by Mack (2010). According to Sekaran \& Bougie (2009) there is no single perfect research design, hence the researcher used both descriptive survey and explanatory research designs to achieve optimal results.

In order to obtain data necessary to draw inferences, the target population included those Deposit-Taking SACCOs that had existed for at least three years since their being licensed. Therefore, the target population was the 110 Deposit-Taking SACCOs that were licensed as at $31^{\text {st }}$ December 2011 in Kenya. To select an optimum sample of 86 Deposit-Taking SACCOs from where data was collected, simple random sampling method was used. Simple random sampling ensured that each Deposit-Taking SACCO had an equal chance of being selected as suggested by Mugenda \& Mugenda (2003). Random sampling was also found suitable by Acharya et al. (2008) who conducted a study to establish website usability impacts on performance of banks.

From each Deposit-Taking SACCO, two managers (from information technology and finance departments) were purposively sampled as the respondents of the study. Mugenda \& Mugenda (2003) contend that a researcher can purposefully select respondents he/she considers to have the 
required information or with capability to provide credible responses. The respondents selected were believed to be conversant with the utilization of mobile communication services within the SACCO and their effect on SACCO's performance. They were, therefore in a position to provide credible responses necessary to make valid conclusions regarding the study objectives.

A self-administered structured questionnaire was used for primary data collection. The questionnaire was divided into various sections as informed by the objectives and the conceptual framework. Gall, Borg \& Gall (1996) recommends a questionnaire as a convenient and the most suitable instrument for data collection in survey as well as statistical research in social and technical research. Administered questionnaires have usually high response rate because they are delivered and collected by the researcher or the assistant (Saunders et al., 2007). In addition, data collected using questionnaires is easier to analyze (Cooper \& Schindler, 2014). Since the positivism philosophy adopted in this study calls for quantitative data for easy generalizations (Babbie, 2010), a structured questionnaire was considered appropriate for data collection.

\section{Empirical Model}

Multiple linear regression analysis was conducted to establish the effect of independent variables (mobile messaging services, mobile call services, mobile email services, mobile chatting services and mobile conferencing services) on the dependent variable as recommended by Jackson (2009). SPSS software application was used to generate composite indices based on arithmetic means for each independent variable and the dependent variable (comprising both financial and non-financial measures) to use in the multiple linear regression model. According to Faraway (2002) and Brooks (2014) multiple linear regression analysis is chosen when the dependent model is continuous and when independent variables are more than one. It was therefore relevant in testing the effect of mobile web services (independent variables) on performance of SACCOs (dependent variable) in this study as the dependent variable was continuous. This is depicted by the model shown below:

$$
\mathrm{Y}=\beta_{0}+\beta_{1} X_{1}+\beta_{2} X_{2}+\beta_{3} X_{3}+\beta_{4} X_{4}+\beta_{5} X_{5}+\varepsilon
$$

Where,

$\mathrm{Y}=$ Performance of the Deposit-Taking SACCO

$\mathrm{X}_{1}=$ Mobile messaging services

$\mathrm{X}_{2}=$ Mobile call services

$\mathrm{X}_{3}=$ Mobile email services

$\mathrm{X}_{4}=$ Mobile chatting services 
$\mathrm{X}_{5}=$ Mobile conferencing services

$\varepsilon=$ error term (accounting for variables other than those specified in the model that explains changes in the dependent variable)

$\beta_{0}=$ constant term

$\beta_{1}$ to $\beta_{5}=$ coefficients of the independent variables

The empirical model above was used to generate coefficients and tstatistics for each independent variable and their corresponding $\mathrm{p}$-values. To determine whether each independent variable had a significant effect on performance of SACCOs, its corresponding coefficient was tested to check whether it was statistically different from zero by checking its $p$-value. If $p$ value of a given coefficient was less than the chosen significance level $(0.05)$ the null hypothesis was rejected and a conclusion drawn that the corresponding variable significantly affected the performance of SACCOs.

\section{Results and Discussion \\ Response Rate}

The study aimed at obtaining responses from a sample of 86 DepositTaking SACCOs in Kenya and therefore 86 questionnaires were issued one for each of the 86 randomly selected Deposit-Taking SACCOs. After checking the completeness and non-response cases of questionnaires, 68 questionnaires were correctly filled representing a response rate of 79.1 percent. Unreturned questionnaires were 10 representing 11.6 percent while the disqualified questionnaires due to incompleteness and inconsistencies were 8 representing 9.3 percent of the total number of issued questionnaires. Table 1 below represents the summary of the response rate.

Table 1: Questionnaire Response Rate

\begin{tabular}{|l|c|c|}
\hline Responses & Values & Percentage \\
\hline Administered questionnaires & 86 & 100 percent \\
\hline Unreturned Questionnaires & 10 & 11.6 percent \\
\hline Disqualified questionnaires & 8 & 9.3 percent \\
\hline Returned and correctly filled questionnaires & 68 & 79.1 percent \\
\hline
\end{tabular}

According to Babbie (2004), Mugenda \& Mugenda (2003) and Saunders et al. (2007), a response rate of 50 percent is adequate, a response rate of 60 percent is good, and a response rate of 70 percent is very good. The response rate of 79.1 percent observed in this study was therefore very good and as such sufficient for further analysis and for drawing conclusions based on the stipulated research objectives. Furthermore, the study's response rate was acceptable as it compared well with similar studies conducted in Kenya such as Kidombo (2007) who achieved a response rate of 64.0 percent, Magutu (2013) who had a response rate of 75 percent and Waithaka et al. (2013) who had a response rate of 69 percent. 


\section{Regression Results}

The regression model used the composite indexes for both the dependent variables (SACCO performance) as well as the independent variables (mobile messaging, mobile call, mobile email, mobile chatting and mobile conferencing services). Arithmetic mean was used to generate the composite indexes of all the variables. To indicate the amount of variation in the performance of SACCOs explained by the independent variables, the coefficient of determination $\left(\mathrm{R}^{2}\right)$ was used. Tables 2,3 and 4 summarize the regression analysis results.

Table 2: Summary Results of Regression Model

\begin{tabular}{|l|l|l|l|}
\hline Model & R & R Square & Adjusted R Square \\
\hline 1 & $.656^{\mathrm{a}}$ & .430 & .384 \\
\hline
\end{tabular}

a. Predictors: (Constant), Mobile Conferencing, Mobile Messaging, Mobile Call, Mobile Chat, Mobile Emai

As shown in the Table $2, \mathrm{R}^{2}$ was 0.430 indicating that the five independent (mobile messaging, mobile call, mobile email, mobile chatting and mobile conferencing services) explained $43.0 \%$ percent of variations in performance of SACCOs, implying that 57.0 percent of variations was explained by other variables outside the model.

Table 3: Anova Results For Model Significance

\begin{tabular}{|c|c|r|r|r|r|r|}
\hline \multicolumn{2}{|c|}{ Model } & Sum of Squares & \multicolumn{1}{c|}{ Df } & Mean Square & F & Sig. \\
\hline \multirow{3}{*}{1} & Regression & 11.494 & 5 & 2.299 & 9.345 & $.000^{\mathrm{b}}$ \\
\cline { 2 - 8 } & Residual & 15.251 & 62 & .246 & & \\
\cline { 2 - 8 } & Total & 26.745 & 67 & & & \\
\hline
\end{tabular}

a. Dependent Variable: Sacco Performance

b. Predictors: (Constant), Mobile Conferencing, Mobile Messaging, Mobile Call, Mobile Chat, Mobile Email

To check the statistical significance of the overall regression model, Anova test was used as shown in Table 3. From Table 3, the overall model was statistically significant $\left(\mathrm{F}_{(5,62)}=9.345, \mathrm{p}=0.000\right)$ implying that the study's independent variables (mobile messaging services, mobile call services, mobile email services, mobile chatting and mobile conferencing services) explained the variations in the dependent variable (performance of DepositTaking SACCOs) and therefore the model was adequate for further hypotheses testing.

Table 4: Regression Coefficients

\begin{tabular}{|l|r|r|r|r|}
\hline \multicolumn{1}{|c|}{ Variable } & \multicolumn{1}{c|}{ B } & \multicolumn{1}{c|}{ Std. Error } & \multicolumn{1}{c|}{ t } & \multicolumn{1}{c|}{ Sig. } \\
\hline (Constant) & 2.169 & .279 & 7.786 & .000 \\
\hline Mobile Messaging Services & .126 & .083 & 1.528 & .048 \\
\hline Mobile Call Services & .123 & .068 & 1.808 & .044 \\
\hline Mobile Email Services & .028 & .081 & .341 & .734 \\
\hline Mobile Chatting Services & .165 & .072 & 2.297 & .025 \\
\hline Mobile Conferencing Services & .044 & .064 & .685 & .496 \\
\hline
\end{tabular}


For hypotheses testing, Table 4 derived from running multiple linear regressions of independent variables on the dependent variable was used. From the regression analysis, it was found that mobile messaging services, mobile call services and mobile chatting services had a positive statistically significant effect on performance of Deposit-Taking SACCOs. However, mobile email services and mobile conferencing services were found to have no statistically significant effect on performance of Deposit-Taking SACCOs. The table below summarizes the outcome of hypotheses testing based on the regression model shown above.

Table 6: Summary Of Hypotheses Testing

\begin{tabular}{|c|c|c|}
\hline Hypothesis & Results & $\begin{array}{l}\text { Remarks on } \\
\text { Hypothesis }\end{array}$ \\
\hline $\begin{array}{l}\text { Ho1: There is no statistically significant effect of mobile } \\
\text { messaging services on performance of Deposit-Taking } \\
\text { SACCOs in Kenya }\end{array}$ & $\begin{array}{l}\beta=0.126 \\
\text { t-value }=1.528 \\
p \text {-value }=0.048\end{array}$ & Reject $\mathrm{H}_{01}$ \\
\hline $\begin{array}{l}\text { Ho2: There is no statistically significant effect of mobile } \text { call services on performance of Deposit-Taking } \\
\text { SACCOs in Kenya }\end{array}$ & $\begin{array}{l}\beta=0.123 \\
\text { t-value }=1.808 \\
p \text {-value }=0.044\end{array}$ & Reject $\mathrm{H}_{02}$ \\
\hline $\begin{array}{l}\text { Ho3: There is no statistically significant effect of mobile } \\
\text { email services on performance of Deposit-Taking } \\
\text { SACCOs in Kenya }\end{array}$ & $\begin{array}{l}\beta=0.028 \\
\text { t-value }=0.341 \\
p \text {-value }=0.734\end{array}$ & $\begin{array}{l}\text { Do Not Reject } \\
\mathrm{H}_{03}\end{array}$ \\
\hline $\begin{array}{l}\text { Ho4: There is no statistically significant effect of mobile } \\
\text { chatting services on performance of Deposit-Taking } \\
\text { SACCOs in Kenya }\end{array}$ & $\begin{array}{l}\beta=0.165 \\
\text { t-value }=2.297 \\
p \text {-value }=0.025\end{array}$ & Reject $\mathrm{H}_{04}$ \\
\hline $\begin{array}{l}\text { Hos: There is no statistically significant effect of mobile } \\
\text { conferencing services on performance of Deposit- } \\
\text { Taking SACCOs in Kenya }\end{array}$ & $\begin{array}{l}\beta=0.044 \\
\text { t-value }=0.685 \\
p \text {-value }=0.496\end{array}$ & $\begin{array}{l}\text { Do Not Reject } \\
\mathrm{H}_{05}\end{array}$ \\
\hline
\end{tabular}

From this study, it can be concluded that use of mobile devices to provide mobile communication services is paramount towards enhancing performance of Deposit-Taking SACCOs and should therefore be encouraged by the management boards of these SACCOs. Findings of this study are corroborated by the study of Maina et al. (2012) who indicated that mobile calls and mobile messaging services had significantly improved performance of manufacturing firms in Kenya. It also agrees with the study of Smits \& Mogos (2013) who found that mobile chatting via social media enhances business capabilities and business performance. The role of communication services such as through use of social media has also been found to enhance communication flows, collaboration and business processes within organizations (Bradbury, 2010). Using social media, contacts can be established with knowledgeable professionals leading to collaborations in project execution, benchmarking in business processes and strategy reviews which enable organizations remain competitive. 
The study is also consistent with that of Tirunillai \& Tellis (2012) who noted the role of communication services in organizations through online services where online users' reviews and blogs provide product and brand specific information compared with other forms of marketing. It is also corroborated by Kimani (2005) who indicated the crucial role played by social media marketing on performance of organizations in Kenya. Additionally, the findings are consistent with the study by Kiganane et al. (2012) which indicated that mobile communication services had a positive effect on organizational performance. Another study by Salia et al. (2011) found that mobile communication services had improved market efficiencies and reduced price variations as a result of availing better up-to date information to citizens.

\section{Conclusion}

The significant role played by mobile communication services towards enhancing performance of Deposit-Taking SACCOs in Kenya has been demonstrated by the findings. The study concluded that the utilization of mobile communication services particularly mobile messaging, mobile call and mobile chatting services by Deposit-Taking SACCOs enhances their performance. Use of mobile communication services such as mobile messaging and mobile call services for official communication within SACCOs should therefore be encouraged by SACCOs' management. The information technology managers in consultation with SACCOs' chief executive officers should also allow and encourage the new methods of mobile communication particularly mobile chatting via social media applications to enhance SACCOs performance as their utilization remains low within SACCOs. Additionally, academicians should collaborate with telecommunication industry players to further develop capabilities of mobile technology devices in order to support the emerging new methods of mobile communication services in order to encourage their utilization within organizations.

\section{Acknowledgement}

To the management of University of Embu and Kenyatta University, we are very thankful that you allowed time to pursue data collection and for facilitating data collection financially. To the Chief Executive Officers of all the Deposit-Taking Savings and Credit Cooperative Societies (SACCOs) in Kenya from where data was collected, we will remain highly indebted to you all.

\section{References:}

1. Abadi, H. R., Kabiry, N. \& Forghani, M. H. (2013). Factors affecting Isfahanian mobile banking adoption based on the Technology 
Acceptance Model. International Journal of Academic Research in Business and Social Sciences, 3(5), 611-623

2. Aboelmaged, M. G. \& Gebba, T. R. (2013). Mobile Banking Adoption: An Examination of Technology Acceptance Model and Theory of Planned Behavior. International Journal of Business Research and Development, 2(1), 35-50

3. Acharya, R. N., Kagan, A., Lingam, S. R. \& Gray, K. (2008). Impact of Website Usability On Performance: A Heuristic Evaluation Of Community Bank Homepage Implementation. Journal of Business \& Economics Research, 6(6), 139-148

4. Babbie, E. R. (2004). The practice of social research. $10^{\text {th }}$ Edition. Belmont, CA: Thomson/Wadsworth

5. Bradbury, D. (2010). Web 2.0 beyond buzz words. Computer Weekly. Available online: http://www.computerweekly.com/news/2240080814/Web-20beyond-the-buzz-words, Last accessed $17^{\text {th }}$ June 2015

6. Brooks, C. (2014). Introductory Econometrics to Finance. Cambridge University Press

7. Cooper, D. R. \& Schindler, P.S. (2014). Business Research Methods, $12^{\text {th }}$ edition, McGraw-Hill: New York

8. Dineshwar, R. \& Steven, M. (2013). An investigation on mobile banking adoption: A case study of Mauritius. Proceedings of $3^{\text {rd }}$ Asia-Pacific Business Research Conference February 2013, Kuala Lumpur, Malaysia, ISBN: 978-1-922069-19-1

9. Evans, N.D. (2002). Business Agility: Strategies for Gaining Competitive Advantage through Mobile Business Solutions. PrenticeHall, Englewood Cliffs, NJ.

10. Faraway, J. (2002). Practical Regression and Anova using $R$. Retrieved on Wednesday $17^{\text {th }}$ April, 2015, http://cran.rproject.org/doc/contrib/Faraway-PRA.pdf.

11. Gall, M. D., Borg, W. R. \& Gall, J. P. (1996). Educational Research $\left(6^{\text {th }} e d\right)$. White Plains, NY: Longman Publishers USA.

12. Government of Kenya (2013). Kenya Vision 2030. Available online: Http://www.theredddesk.org/sites/default/files/vision_2030_brochure july_2007. pdf, Last accessed: 5th April 2014

13. Gunasekaran, A., Ngai, E.W.T. \& McGaghey, R.E. (2006). Information Technology and Systems Justification: A review for research and applications. European Journal of Operations Research, 173, 957-983

14. International Telecommunication Union (2013). ICT Facts and Figures. Available online:http://www.itu.int/en/ITU- 
D/Statistics/Documents/facts/ICTFactsFigures2013-e.pdf, accessed: 10th May 2014

15. Jackson, S. (2009). Research Methods and Statistics: A Critical Thinking Approach, $3^{\text {rd }}$ edition. Waldsworth Cengage Learning, United States of America.

16. Jensen, R. (2007). The Digital Provide: Information (Technology), Market Performance, and Welfare in the South Indian Fisheries Sector. The Quarterly Journal of Economics, 122(3), 879-924

17. Kagan, Acharya, Rao \& Kodepaka (2005). Does Internet Banking Affect the Performance of Community Banks? Presented at the American Agricultural Economics Association Annual Meeting, Providence, Rhode Island, July 24-27, 2005

18. Kidombo, H. J. (2007). Human Resource Strategic Orientation, Organizational Commitment and Firm Performance: The case of Large Private Manufacturing Firms in Kenya. PhD Thesis, University of Nairobi

19. Kiganane, L. M., Bwisa, H. \& Kihoro, J. M. (2012). Assessing influence of firm characteristics on the effect of mobile phone services on firm performance. International Journal of Economics and Management Sciences, 1(10), 12-21

20. Kimani, E. (2015). Role of social media marketing on organisational performance in Kenya. IOSR Journal of Business and Management, 17(1), 101-105

21. Liang, T-P., Huang, C-W., Yeh, Y-H. \& Lin, B. (2007). Adoption of mobile technology in business: a fit-viability model. Industrial Management \& Data Systems, 107(8), 1154-1169

22. Mack, L. (2010). The Philosophical Underpinnings of Educational Research. Polyglossia, 9, 5-11

23. Magutu, P.O. (2013). Supply chain strategies, technology and performance of large-scale manufacturing firms in Kenya. PhD Thesis, University of Nairobi

24. Maina, J. M. \& Gekara, M. G. (2014). Effects of mobile money transfer services on small and medium enterprises financial performance: a case of Nairobi County in Kenya. International Scientific Research Journal in Business and Management, 2(2), 15-27

25. Maina, L. N., Bwisa, H. \& Kihoro, J.M. (2012). Mobile phone services and their perceived influence on performance of manufacturing firms: A case study of Thika Town in Kenya. Asian Journal of Business and Management Sciences, 1(11), 116-130

26. Matumo, N. G., Maina, K. E. \& Njoroge, N. N. (2013). The impact of front office Sacco activity on Sacco performance in Kenya; A case of study of Meru South and Maara district in Tharaka Nithi County in 
Kenya. Global Advanced Research Journal of Management and Business Studies, 2(5), 285-290

27. Mugambi, D. N., Njeru, A., Memba, F. \& Ondabu, I. T. (2015). Effect of Cash Management on Financial Performance of Deposit Taking SACCOs in Mount Kenya Region. International Journal of Scientific and Research Publications, 5(2), 1-7

28. Mugenda, O. \& Mugenda, A. (2003). Research methods, quantitative and qualitative approaches, Nairobi Acts Press

29. Mumanyi, E. A. L. (2014). Challenges and opportunities facing SACCOs in the current devolved system of government of Kenya: A case study of Mombasa County. International Journal of Social Sciences and Entrepreneurship, 1(9), 288-314.

30. Njeri, K. O. (2012). Effects of financial innovation on the financial performance of Deposit-Taking SACCOs in Nairobi, County. Master's Thesis, University of Nairobi

31. Olando, C. O., Mbewa, M. O. \& Jagongo, A. (2012). Financial Practice as a Determinant of Growth of Savings and Credit Co-Operative Societies' Wealth. International Journal of Business and Social Science, 3(24), 204-219

32. Orotin, P., Quisenbery, W. \& Ted, S. (2013). A study on factors facilitating access to Mobile Phone Money in Uganda. Greener Journal of Business and Management Studies, 3(6), 279-291

33. Rangone, A. \& Renga, F. (2006). B2e Mobile Internet: an exploratory study of Italian applications. Business Process Management Journal, 12(3), 330-343

34. Rao, H., Sally, L. \& Troshani, I. (2007). A conceptual framework and propositions for the acceptance of mobile services, Journal of Theoretical and Applied Electronic Research, 2(2), 61-73.

35. Salia, M., Nuamah, N. N. \& Steel, W. F. (2011). Effects of mobile phone use on artisanal fishing market efficiency and livelihoods in Ghana. The Electronic Journal on Information Systems in Developing Countries, 47(6), 1-26

36. Saunders, M., Lewis, P. \& Thornhill, A. (2007). Research methods for business students, $5^{\text {th }}$ edition, Great Britain, Prentice Hall

37. Savings Plus. (2010). A brief history of savings and credit cooperatives. South Africa: Future Link Technologies.

38. SASRA (2011). SACCO Supervision Report 2011. Available online: http://www.sasra.go.ke. Last accessed: $27^{\text {th }}$ April 2015.

39. SASRA (2013). SACCO Supervision Annual report 2013. Available online: http://www.sasra.go.ke. Last accessed: 27 ${ }^{\text {th }}$ April 2015. 
40. SASRA (2014). SACCO Supervision Annual report 2014. Available online: http://www.sasra.go.ke. Last accessed: $24^{\text {th }}$ October 2015.

41. SASRA (2015). Deposit-taking SACCO societies licensed by the SACCO societies regulatory authority. Available: http://www.sasra.go.ke/index.php/regulation/licensedsaccos\#.VPAnNSy4cvg. Accessed $27^{\text {th }}$ February 2015.

42. Scornavacca, E. \& Barnes, S. J. (2006). Barcode enabled mcommerce: strategic implications and business models. International Journal of Mobile Communications, 4(2), $163-177$.

43. Sekaran, U. \& Bougie, R. (2009). Research Methods for Business: A Skill Building Approach, $5^{\text {th }}$ edition, John Wiley \& Sons Ltd., United Kingdom

44. Stoica, O., Mehdian, S. \& Sargu, A. (2015). The Impact of internet banking on the performance of Romanian Banks: DEA and PCA approach. Procedia Economics and Finance, 20, 610-622

45. Tirunillai, S. \& Tellis, G. (2012). Does Chatter Matter? The Impact of Online Consumer Generated Content on a Firm's Financial Performance, Marketing Science, 31(2), 198-215.

46. Vuolle, M. (2010). Productivity impacts of a mobile office service. International Journal of Services Technology and Management, 14 (4), 326-342.

47. Wahla, R. S. \& Awan, A. G. (2014). Mobile Phones Usage and Employees' Performance: A Perspective from Pakistan. International Journal of Academic Research in Accounting, Finance and Management Science, 4(4), 153-165

48. Waithaka, S.T., Kimani, T. M., Korir, J. \& Muathe, S. (2013). Environmental Factors that Influence Supply Chain Management Implementation in the Manufacturing Industries in Kenya: A Case of Manufacturing Industries in Nairobi, Kenya. ABC Journal of Advanced Research, 1(2), 42-49

49. World Council of Credit Unions. (2013). International Credit Union Day: A Brief History. Retrieved from http://www.woccu.org/events/icuday/history. Last accessed: $27^{\text {th }}$ April 2015.

50. Zhang, J. \& Mao, E. (2008). Understanding the Acceptance of Mobile SMS Advertising among Young Chinese Consumers. Psychology \& Marketing, 25(8), 787-805. 